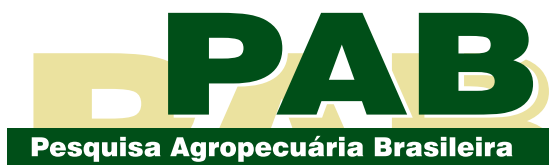

ISSN 1678-3921

Journal homepage: www.embrapa.br/pab

For manuscript submission and journal contents, access: www.scielo.br/pab

Rodrigo Yudi Fujimoto(1凶) Rudã Fernandes Brandão Santos ${ }^{(2)}(3$, Gabriela Pala ${ }^{(3)}$,

Sílvia Umeda Gallani(3)

Gustavo Moraes Ramos Valladão ${ }^{(3)}($,

Gisele Cavalcante Morais ${ }^{(4)}$,

James Tony Lee ${ }^{(5)}$,

Natalino da Costa Sousa(6)

Fernanda dos Santos Cunha( ${ }^{(7)}$,

Alexandre Nizio Maria ${ }^{(1)}$,

Paulo César Falanghe Carneiro(1) and

Fabiana Pilarski(3)

(1) Embrapa Tabuleiros Costeiros, Avenida Beira Mar, no 3.250, Jardins, CEP 49025-040 Aracaju, SE, Brazil.

E-mail: ryfujim@hotmail.com, alexandre.maria@embrapa.br paulo.carneiro@embrapa.br

(2) Universidade Federal de Pernambuco, Departamento de Bioquímica, Laboratório de Enzimologia, Avenida Prof. Moraes Rego, $\mathrm{s} / \mathrm{n}^{\circ}$, Cidade Universitária, CEP 50670-420 Recife, PE, Brazil. E-mail: ruda_fernandes@hotmail.com

(3) Universidade Estadual Paulista, Centro de Aquicultura, Laboratório de Microbiologia e Parasitologia de Organismos Aquáticos, Via de Acesso Prof. Paulo Donato Castellane, s/no , Rural, CEP 14884-900 Jaboticabal, SP, Brazil.

E-mail: gabi.caunesp@gmail.com, sigallani@hotmail.com, gmrvalladao@gmail.com fabianap@caunesp.unesp.br

(4) Universidade Federal do Paraná, Centro de Estudos Marinhos, Laboratório de Bentos, Avenida Beira-Mar, s/no, Pontal do Sul, CEP 83255-976 Pontal do Paraná, PR, Brazil. E-mail: gisellymorais@gmail.com

(5) Universidade Federal do Pará, Instituto de Geociências, Faculdade de Oceanografia, Rua Augusto Correa, no 01, Campus Universitário do Guamá, CEP 66075-110 Belém, PA, Brazil. E-mail: james@ufpa.br

(6) Universidade Federal do Pará, Alameda Leandro Ribeiro, $s / n^{\circ}$, Aldeia, CEP 68600-000 Bragança, PA, Brazil. E-mail: natal159@yahoo.com.br

(7)Universidade Tiradentes, Avenida Murilo Dantas, no 300, Farolândia, CEP 49032-490 Aracaju, SE, Brasil. E-mail:fe.cunha_@hotmail.com

\section{Supplementation with arginine in the diet of Nile tilapia reared in net cages}

\begin{abstract}
The objective of this work was to evaluate the effect of dietary arginine concentrations on the health status of Nile tilapia (Oreochromis niloticus) cultivated in cages. The experiment was carried out in a completely randomized design with four treatments $(2.3,2.9,3.5$, and $4.1 \%$ arginine in dry matter) and three replicates, in 12 net cages of $8 \mathrm{~m}^{3}$, containing 4,000 sexually reverted tilapia $\left(63 \pm 20 \mathrm{~g}\right.$, at $\left.500 \mathrm{fish}^{-3}\right)$. Fish productive performance and health were evaluated. Biochemical, hematological, and immunological parameters, as well as the morphological aspects of gills and liver, were evaluated. Arginine inclusion did not cause significant differences in fish growth performance. However, arginine supplementation at $3.5 \%$ concentration improved the biochemical parameters and leucocyte counts, consequently improving the immune system. The arginine concentration of $4.1 \%$ caused lipid degeneration, shown by the increase of alanine aminotransferase and the decrease of albumin, urea, lactate, and glucose. Arginine supplementation above $2.3 \%$ and below $3.5 \%$, in the diets of tilapia reared in cages, improves fish immune system, without adverse morphological and physiological effects.
\end{abstract}

Index terms: Oreochromis niloticus, biochemistry, haematology, histology, nutritional requirement.

\section{Suplementação com arginina na dieta de tilápia-do-nilo produzida em tanques-rede}

Resumo - O objetivo deste trabalho foi avaliar o efeito de concentrações de arginina dietética sobre a saúde da tilápia-do-nilo (Oreochromis niloticus), em tanques-rede. $\mathrm{O}$ experimento foi realizado em delineamento inteiramente casualizado, com quatro tratamentos $(2,3,2,9,3,5$ e $4,1 \%$ de arginina em relação à matéria seca na dieta) e três repetições, em 12 tanques-rede de 8 $\mathrm{m}^{3}$, com 4.000 tilápias revertidas sexualmente $\left(63 \pm 20 \mathrm{~g}, 500\right.$ peixes $\left.\mathrm{m}^{-3}\right)$. Determinaram-se o desempenho produtivo e a saúde dos peixes. Avaliaram-se os parâmetros bioquímicos e hematoimunológicos e os aspectos morfológicos das brânquias e do fígado. A inclusão de arginina não proporcionou diferenças significativas no desempenho produtivo. Porém, a suplementação de arginina a 3,5\% de concentração melhorou os parâmetros bioquímicos e de contagem de leucócitos, tendo consequentemente melhorado o sistema imunológico. A concentração de arginina a 4.1\% causou degeneração lipídica, representada pelo aumento dos níveis da alanina aminotransferase e pela diminuição dos níveis de albumina, ureia, lactato e glicose. A suplementação com arginina acima de $2,3 \%$ e abaixo de $3,5 \%$, nas dietas de tilápias criadas em tanquesrede, promove melhoras no sistema imunológico dos peixes, sem provocar efeitos morfológicos e fisiológicos deletérios.

Termos para indexação: Oreochomis niloticus, bioquímica, hematologia, histologia, exigência nutricional. 


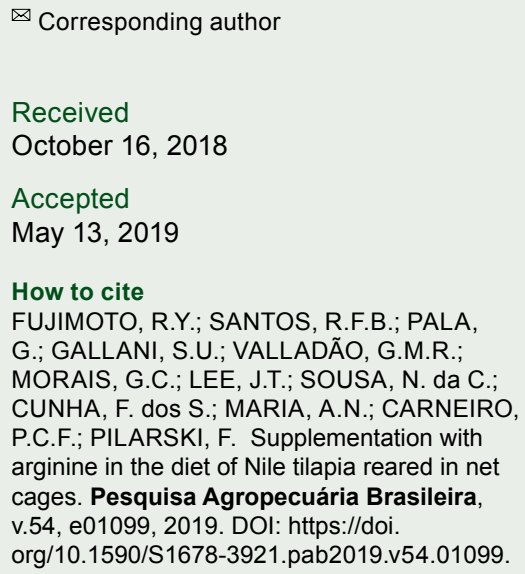

\section{Introduction}

Fish raised in cages are in constant stressful situations because of the high-stocking density, water physicochemical variations, and constant water stream (Sadhu et al., 2014; Calabrese et al., 2017). These stressors unbalance the host-pathogen-environment relationship, provoking diseases (Ojwala et al., 2018).

Furthermore, those conditions can also induce muscle fatigue and increase the energy demand and metabolic excretion, decreasing the nutrient utilization, with a consequent increase of nutritional requirements (Rodnick \& Planas, 2016; Hvas et al., 2017). Therefore, fish in cages need balanced diets that attend this high nutritional requirement and provide animal welfare and health (Rodnick \& Planas, 2016). Among the essential nutrients, arginine stands out as an essential and functional amino acid for fish because it participates in the synthesis of muscle protein, growth hormone $(\mathrm{GH})$, and insulin-like growth factor type 1 (IGF1), besides being a precursor of polyamines and nitric oxide, which are substances that have important roles in modulating the immune response of fish $(\mathrm{Tu}$ et al., 2015).

Among fish farmed in cages, Nile tilapia (Oreochromis niloticus L.) is the most cultivated species in this production system in Brazil. It is noteworthy that both young and adult fish, cultivated at densities above $40 \mathrm{~kg} \mathrm{~m}^{-3}$ are more susceptible to infections, bacteria and parasites (Zago et al., 2014). However, the nutritional requirement of arginine and its effects on the health improvement of farmed tilapia in net cages are not known. Therefore, the dietary arginine supplementation for Nile tilapia in net cages could be a solution to mitigate the stress effects inherent to this production system.

The objective of this work was to evaluate the effect of dietary arginine concentrations on the health status of Nile tilapia cultivated in cages.

\section{Materials and Methods}

The experiment was conducted in a commercial tilapia farm in the municipality of Arealva, in the state of São Paulo, Brazil. Twelve cages of $8 \mathrm{~m}^{3}$ each were used, containing 4,000 sex-reversed Nile tilapia $\left(63 \pm 20 \mathrm{~g}, 500\right.$ fish $\left.\mathrm{m}^{-3}\right)$ in each one, in the second growth-phase.

A completely randomized design was carried out with four treatments corresponding to arginine concentrations in the diet $(2.3,2.9,3.5$, and $4.1 \%$ arginine in relation to dry matter - DM), and three replicates, for 45 days. During the experimental period, fish were fed twice a day (ad libitum) and feed daily values were measured.

Water quality variables like temperature, $\mathrm{pH}$, dissolved oxygen, and total ammonia were daily monitored with the help of the multiparameter probe YSI Professional Plus (YSI, Yellow Springs, OH, USA).

The experimental proceedings were approved by the Committee on Ethics and Animal Welfare (CEBEA) under the protocol number 028056/13. Before handling, all fish were anesthetized with an immersion bath in clove oil solution $\left(60 \mathrm{mg} \mathrm{L}^{-1}\right)$.

A commercial diet $(2.3 \%$ arginine) was used as a control (Trouw Nutrition, Pitangueiras, SP, Brazil), with the following bromatological composition: $35 \%$ crude protein; $4.39 \%$ ethereal extract; $35 \%$ crude fiber; 9.81\% mineral; $1.82 \%$ calcium; $1.31 \%$ phosphorus; $4.99 \%$ glutamic acid; and $2.03 \%$ lysine. The base diet consisted of fish meal, soybean meal, and corn gluten as protein sources, and soybean oil as lipid source. From the base diet, with $2.3 \% \mathrm{DM}$ and arginine: lysine ratio of 1.13 , according to recommendations of Furuya et al. (2004), L arginine (synthetic arginine) was added at $0.6,1.2$, and $1.8 \%$, resulting in diets with $2.9,3.5$, and $4.1 \%$ arginine in relation to dry matter. The arginine:lysine ratios were 1.46, 1.72, and 2.01, respectively (also produced by Trouw Nutrition), with particle size between 4-6 $\mathrm{mm}$. 
Two biometries were performed, one at the beginning and other at the end of experiment, to measure fish weight $(\mathrm{g})$ and length $(\mathrm{cm})$. All fish of each cage were weighed to compose the total biomass, and a subsample of 150 fish was collected for determination of individual weight and length. The productive performance indices were determined for gain in percentage of biomass $(\mathrm{BG} \%=$ final lot weight / initial lot weight $\times 100$ ), apparent feed conversion $(\mathrm{AFC}=$ feed intake / biomass gain of the lot), and specific growth rate SGR $=100 \times$ (In final weight - In initial weight / days of experiment).

At the end of the experiment, 24 fish were randomly captured from each treatment, and anesthetized for collection of blood sample by puncturing the caudal vessel. For $10 \mu \mathrm{L}$ blood aliquot, $2.0 \mathrm{~mL}$ of citrate formaldehyde was added to perform the erythrocyte count in the Neubauer chamber. Another aliquot of blood was used to evaluate the hematocrit, centrifuging at $1,500 \mathrm{~g}$ for $5 \mathrm{~min}$ (Goldenfarb et al., 1971). Hemoglobin concentration in blood was evaluated by the cyanomethaemoglobin method (Collier, 1944), and hematimetric indexes such as mean corpuscular volume (MCV), mean corpuscular hemoglobin $(\mathrm{MCH})$, and mean corpuscular hemoglobin concentration (MCHC) were determined according to Wintrobe (1934). Blood extensions were colored with May-Grünwald-Gyemsa-Wright stain for further total and differential count of thrombocytes and leukocytes. With another blood aliquot, plasma was obtained by centrifugation in microtubes at 1,372 $g$ for $5 \mathrm{~min}$, for the spectrophotometric evaluations of the following biochemical parameters: glucose, by Trinder's method of glucose oxidase (GOD-Trinder); aspartate aminotransferase (AST), by the UVkinetic method recommended by the International Federation of Clinical Chemistry (IFCC); alanine aminotransferase (ALT), by the UV-kinetic method (UV-IFCC); total proteins, by the biuret method; urea, determined by the enzymatic-colorimetric system (urea CE Labtest, urease method); albumin (bromocresol method); creatinine (Lustosa Basques' method); and lactate dehydrogenase (LDH), by Trinder's enzymatic method). Standardized commercial kits (Labtest Diagnóstica S.A., Lagoa Santa, MG, Brazil) were used. Serum globulin levels were obtained by the difference between total proteins and albumin; and the albumin: globulin ratio was obtained by dividing the albumin values and globulin.

Indicators of the innate immune system were also evaluated, such as leukocyte respiratory activity and complement pathway protein activity, according to the method described by Biller-Takahashi et al. (2012, 2013).

In addition to the productive, biochemical, and hematoimmunological performance analyses, the morphological aspects of gills and liver were also evaluated. These analyses were performed at the end of the experimental period in five animals of subsample of each cage. Fish were euthanized by deepening of the anesthetic plane, followed by medullary section.

Gills fragments (first branchial arch) and liver were extracted, fixed in buffered formaldehyde $(10 \%)$ for 24 hours and, then, washed and preserved in 70\% alcohol. Subsequently, the samples were immersed in alcoholic series and included in Paraplast Plus (Sigma-Aldrich, Darmstadt, HE, Germany). After the inclusion, fragments were cut into $5 \mu \mathrm{m}$ thickness in an automatic microtome LEICA-RM-2245 (Leica Biosystem, Wetzlar, HE, Germany). The histological sections were then subjected to hematoxylin / eosin (HE) staining. These procedures are in accordance with those recommended by Behmer et al. (1976).

The data were subjected to normality and homoscedasticity assumptions, and were subsequently subjected to the analysis of variance, at $1 \%$ probability. In the case of significant $\mathrm{F}$, the Tukey's test, at 5\% probability, was used for the mean comparisons.

\section{Results and Discussion}

The mean values of the water quality parameters in the tanks were: temperature, $25.3 \pm 1.13^{\circ} \mathrm{C}$; dissolved oxygen, $3.75 \pm 0.87 \mathrm{mg} \mathrm{L} \mathrm{L}^{-1} ; \mathrm{pH}, \quad 7.47 \pm 0.24$; and toxic ammonia, $0.0055 \pm 0.004 \mathrm{mg} \mathrm{L}^{-1}$. This means values were in ideal range to tilapia culture in cages (Marengoni et al. 2017).

No differences were observed for the biomass gain, specific growth rate, and apparent feed conversion (Table 1), similarly to what has been found in other species such as Salmo solar (Berge et al., 1997), Salmo gairdneri (Kaushik et al., 1988), Catla catla (Zehra \& Khan, 2013), and Trachinotus ovatus (Lin et al., 2015). The $2.3 \%$ arginine concentration attends to the nutritional requirement observed by Furuya et al. 
(2004), in laboratory tests; however, in this large-scale production conditions, the arginine concentration in the diet did not attend the requirements of tilapia in cages to maintain their health.

That modulation of the nutritional requirement of tilapia from 2.3 to $2.9-3.5 \%$ arginine was observed (Table 2). Arginine elevation increased the glucose and lactate, probably due the production of nitric oxide by arginine activity - a potent vasodilator -, increasing the blood flow. Vasodilation caused by nitric oxide allows supply of nutrients to tissues, removal of lactate from blood cells and, consequently, an increase of glucose and lactate concentrations (Sales et al., 2005). In addition, an increase of plasmatic albumin was observed in the supplementation of arginine up to $3.5 \%$, which resulted in the increase of amines in the nitrogen metabolism, also increasing the catabolism of proteins with a consequent release of urea. Oliva-Teles et al. (2017) also observed an increased urea release in Sparus aurata fed diets containing 2.58 and 3.25\% arginine.

Furthermore, the hematological analysis suggests the need to review the recommended level of arginine, due fish at $2.3 \%$ concentration showed the highest values of $\mathrm{MCH}$ and $\mathrm{MCHC}$, indicating oxygen uptake need (Cengizler et al., 2017). An increase of defense cells was observed with the increasing arginine concentration, which was also observed by Chen et al. (2015) and Zhou et al. (2015) in Cyprinus carpio and Pelteobagrus fulvidraco, respectively. Total leukocytes, lymphocytes, thrombocytes, and neutrophils were increased with the arginine supplementation of 2.9 and/or 3.5\% (Table 3). The increase of these cells can be due to the production of nitric oxides that prevents the adhesion of leukocytes to the endothelium, which increases the concentration of these cells in the blood plasma (Cerqueira \& Yoshida, 2002). In addition, arginine promotes the increasing production of polyamines, which are important substrates for cell proliferation ( $\mathrm{Li}$ et al., 2009).

Morphological changes in the gills and liver are also indicative of the need to review the nutritional requirement of arginine. The gills of fish in the control treatment showed edema with epithelial detachment, intense hyperplasia with lamellar fusion, and congestion, which caused aneurysms in the secondary lamellae of gills (Figure 1). Possibly, this was responsible for higher $\mathrm{MCH}$ and $\mathrm{MCHC}$ in the control treatment $(2.3 \%$ arginine $)$ to compensate the failure of oxygen captured by the gills. Though, up to $4.1 \%$ concentration, a reduction of these damages was observed in the gill morphology of tilapia.

Table 1. Mean values ( \pm SD) of productive performance parameters of Nile tilapia (Oreochromis niloticus) fed diets with different levels of arginine inclusion based on percentage of dry matter (DM).

\begin{tabular}{lccccc}
\hline Productive performance & Control & & Arginine & \multicolumn{2}{c}{ P-value } \\
\cline { 3 - 5 } & $2.3 \% \mathrm{DM}$ & $2.9 \% \mathrm{DM}$ & $3.5 \% \mathrm{DM}$ & $4.1 \% \mathrm{DM}$ \\
\hline Biomass gain (\%) & $161.11 \pm 10$ & $168.54 \pm 13$ & $190.55 \pm 10$ & $177.84 \pm 34$ \\
Specific growth rate (\%) & $2.04 \pm 0.08$ & $2.09 \pm 0.11$ & $2.26 \pm 0.07$ & $2.16 \pm 0.27$ & 0.049 \\
Feed conversion & $1.34 \pm 0.13$ & $1.22 \pm 0.14$ & $1.15 \pm 0.09$ & $1.15 \pm 0.10$ \\
\hline
\end{tabular}

Table 2. Biochemical indicators of Nile tilapia (Oreochromis niloticus) fed diets supplemented with different concentrations of $\operatorname{arginine}{ }^{(1)}$.

\begin{tabular}{|c|c|c|c|c|c|c|}
\hline \multirow{2}{*}{$\begin{array}{l}\text { Indicador } \\
\left(\mathrm{mg} \mathrm{dL}^{-1}\right)\end{array}$} & \multirow{2}{*}{$\begin{array}{c}\text { Control } \\
2.3 \% \mathrm{DM} \\
\end{array}$} & \multicolumn{3}{|c|}{ Arginine } & \multirow[t]{2}{*}{$\mathrm{F}$} & \multirow[t]{2}{*}{ P-value } \\
\hline & & $2.9 \% \mathrm{DM}$ & $3.5 \% \mathrm{DM}$ & $4.1 \% \mathrm{DM}$ & & \\
\hline Total protein & $3.67 \pm 0.3$ & $3.16 \pm 0.4$ & $3.00 \pm 0.4$ & $3.59 \pm 0.5$ & 0.98 & 0.59 \\
\hline Albumin & $0.95 \pm 0.1 \mathrm{ab}$ & $0.92 \pm 0.1 \mathrm{ab}$ & $1.01 \pm 0.13 \mathrm{a}$ & $0.87 \pm 0.1 b$ & 4.26 & 0.0076 \\
\hline Urea & $3.06 \pm 1.25 \mathrm{a}$ & $4.29 \pm 1.17 \mathrm{ab}$ & $4.4 \pm 1.71 b$ & $3.59 \pm 1.38 \mathrm{ab}$ & 2.80 & 0.047 \\
\hline Lactate & $46.41 \pm 18 \mathrm{a}$ & $78.65 \pm 19 \mathrm{c}$ & $66.54 \pm 17 \mathrm{bc}$ & $59.26 \pm 23 \mathrm{ab}$ & 6.74 & 0.009 \\
\hline Glucose & $63.93 \pm 15 \mathrm{ab}$ & $66.14 \pm 12 \mathrm{ab}$ & $73.68 \pm 23 a$ & $49.12 \pm 22 b$ & 3.16 & 0.03 \\
\hline Aspartate transaminase (AST) & $77.78 \pm 50$ & $69.3 \pm 38$ & $48.11 \pm 15$ & $57.75 \pm 38$ & 1.77 & 0.1615 \\
\hline Alanine aminotransferase (ALT) & $4.91 \pm 1.69 \mathrm{a}$ & $3.99 \pm 1.89 \mathrm{a}$ & $4.51 \pm 1.53 \mathrm{a}$ & $7.13 \pm 3.67 b$ & 8.90 & 0.0002 \\
\hline
\end{tabular}

${ }^{(1)}$ Means followed by equal leters do not differ, by Tukey's test, at $5 \%$ probability. 
Table 3. Hematological parameters of Nile tilapia (Oreochromis niloticus) fed diets containing different levels of arginine inclusion $^{(1)}$.

\begin{tabular}{|c|c|c|c|c|c|c|}
\hline \multirow[t]{2}{*}{ Hematological parameter } & \multirow{2}{*}{$\begin{array}{c}\text { Control } \\
2.3 \% \mathrm{DM}\end{array}$} & \multicolumn{3}{|c|}{ Arginine } & \multirow[t]{2}{*}{$\mathrm{F}$} & \multirow[t]{2}{*}{ P-value } \\
\hline & & $2.9 \% \mathrm{DM}$ & $3.5 \% \mathrm{DM}$ & $4.1 \% \mathrm{DM}$ & & \\
\hline Erythrocytes $\left(10^{6}\right)$ & $1.99 \pm 0.49$ & $1.90 \pm 0.37$ & $1.84 \pm 0.23$ & $1.64 \pm 0.29$ & 2.73 & 0.05 \\
\hline Hemoglobin $\left(\mathrm{g} \mathrm{dL}^{-1}\right)$ & $7.32 \pm 0.9$ & $7.11 \pm 1.7$ & $7.11 \pm 0.9$ & $7.57 \pm 0.9$ & 0.45 & 0.721 \\
\hline Hematocrit (\%) & $35.70 \pm 5.2$ & $38.00 \pm 3.2$ & $38.00 \pm 2.2$ & $34.80 \pm 3.2$ & 3.02 & 0.35 \\
\hline $\mathrm{MCV}(\mathrm{fL})$ & $196.0 \pm 50.0$ & $212.0 \pm 63.0$ & $210.0 \pm 27.0$ & $221.0 \pm 45.0$ & 0.51 & 0.68 \\
\hline $\mathrm{MCH}(\mathrm{pg})$ & $40.26 \pm 10 \mathrm{ab}$ & $37.24 \pm 12 \mathrm{a}$ & $38.03 \pm 7.5 \mathrm{ab}$ & $46.56 \pm 9.2 b$ & 2.92 & 0.04 \\
\hline $\mathrm{MCHC}\left(\mathrm{g} \mathrm{dL}^{-1}\right)$ & $21.20 \pm 2.4 \mathrm{a}$ & $17.11 \pm 3.2 b$ & $17.83 \pm 2.4 \mathrm{~b}$ & $20.93 \pm 2.5 \mathrm{a}$ & 8.79 & 0.0002 \\
\hline Total leukocytes (n..$\left.^{\circ} \mu \mathrm{L}^{-1}\right)$ & $24,429 \pm 871 \mathrm{a}$ & $28,732 \pm 842 b$ & $29,753 \pm 1,919 b c$ & $31,069 \pm 989 \mathrm{c}$ & 40 & 0.0001 \\
\hline Lymphocytes $\left(\mathrm{n}^{\circ}{ }^{\circ} \mu \mathrm{L}^{-1}\right)$ & $18,987 \pm 787 \mathrm{a}$ & $22,297 \pm 721 b$ & $22,994 \pm 1,224 b$ & $24,543 \pm 761 \mathrm{c}$ & 50.63 & 0.0001 \\
\hline Monocytes $\left(\mathrm{n}^{\circ}{ }^{\circ} \mu \mathrm{L}^{-1}\right)$ & $2,655 \pm 273 a$ & $2,751 \pm 478 \mathrm{a}$ & $3,421 \pm 269 b$ & $3,494 \pm 166 b$ & 14.71 & 0.0001 \\
\hline Neutrophils (n..$\left.^{o} \mu \mathrm{L}^{-1}\right)$ & $2,477 \pm 398 \mathrm{a}$ & $3,163 \pm 394 b$ & $2,990 \pm 499 \mathrm{ab}$ & $2,720 \pm 202 a b$ & 3.90 & 0.02 \\
\hline Basophils $\left(\mathrm{n}^{\circ}{ }^{\circ} \mu \mathrm{L}^{-1}\right)$ & $310.0 \pm 168.0$ & $401.0 \pm 153.0$ & $297.0 \pm 19.0$ & $310.0 \pm 9.0$ & 1.002 & 0.41 \\
\hline Thrombocytes $\left(\mathrm{n}^{\circ}{ }^{\circ} \mu \mathrm{L}^{-1}\right)$ & $4,152 \pm 292 \mathrm{ab}$ & $3,667 \pm 264 a$ & $4,338 \pm 381 b$ & $4,143 \pm 291 \mathrm{ab}$ & 4.57 & 0.01 \\
\hline Complement & $1.00 \pm 0.34$ & $0.52 \pm 0.23$ & $1.83 \pm 0.9$ & $1.12 \pm 0.45$ & 1.19 & 0.324 \\
\hline Respiratory burst (D.O.) & $0.57 \pm 0.1 \mathrm{a}$ & $0.46 \pm 0.03 b$ & $0.51 \pm 0.04 \mathrm{ab}$ & $0.53 \pm 0.08 \mathrm{ab}$ & 7 & 0.0005 \\
\hline
\end{tabular}

${ }^{(1)}$ Means followed by equal leters do not differ, by Tukey's test, at $5 \%$ probability.
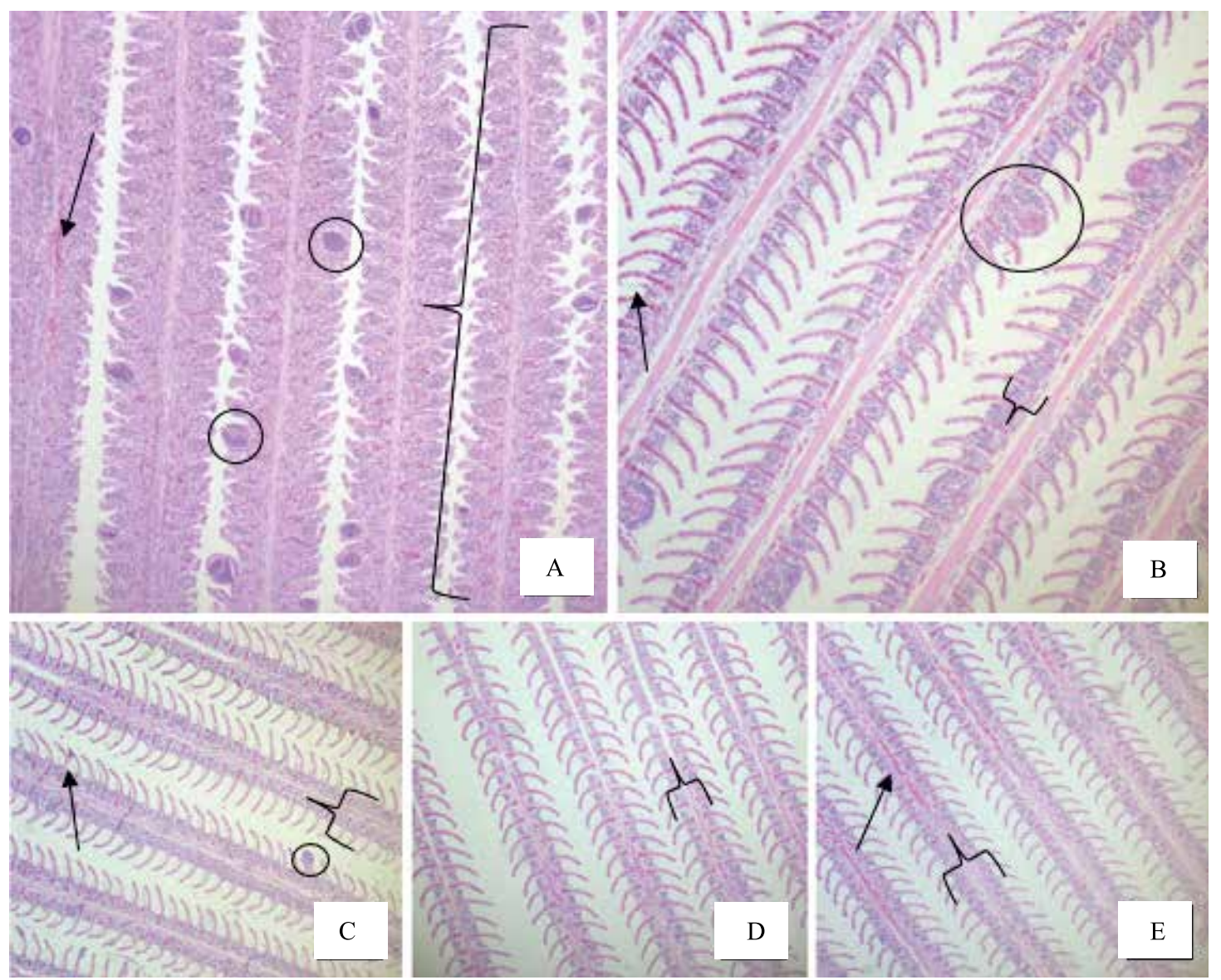

Figure 1. Photomicrography of gills of Nile tilapia (Oreochromis niloticus) produced in net cages with dietary arginine supplementation. A, control treatment, 2.3\% arginine - congestion (arrow), lamellar fusion (key), and parasites (circle), 100X, HE stain. B, 2.3\% arginine - moderate hyperplasia (key), epithelial detachment (arrow), and aneurysm (circle), 1000X, HE stain. C, 2.9\% arginine - moderate hyperplasia (key), epithelial detachment (arrow), and parasite (circle), 100X, HE stain. D, $3.5 \%$ arginine - moderate hyperplasia (key), 100X, HE stain. E, 4.1\% arginine - moderate hyperplasia (key), and congestion (arrow) 100X, HE stain. 
In liver, changes were also observed in the control group (commercial diet at $2.3 \%$ arginine) as lipid degeneration, characterized by the intense vacuolization found in hepatocytes (Figure 2), and necrosis foci. Because of the trial period (45 days), an arginine deficiency is unlikely to occur, thus changes in the gills may have occurred as a result of contaminants in the water. Excessive carbohydrate intake, which may have increased the synthesis of fatty acids, with formation of excessive triglyceride levels in hepatocytes (Silva \& Gonçalves, 2008).

The reduction of these alterations was observed in the higher levels of arginine inclusion; however, no lipid degeneration was observed in the treatments with 2.9 and $3.5 \%$ of the amino acid (Figure 2). L-arginine improves the hepatic cells resistance by improving microcirculation among hepatocytes, and reducing the deleterious effects of toxic substances (Saad, 2012).
A possible toxic effect was observed in the concentration of $4.1 \%$ with the presence of necrosis and occurrence of pyknotic nuclei (Figure 2), which indicates that the arginine requirement is between 2.9 and $3.5 \%$ for tilapia reared in cages. In the treatment with $4.1 \%$ arginine, the elevation of the enzyme alanine aminotransferase (ALT) was also observed. This enzyme is used as an indicator of cellular damage in fish (Rahimnejad \& Lee, 2014). The decrease of albumin value in this treatment, associated with elevated alanine aminotransferase (ALT), indicates a clinical sign of lipid degeneration (Silva \& Gonçalves, 2008).

The toxicity provoked by arginine may be due to an amino acid imbalance in the diet, provoking a reduction of plasmatic urea in the treatment with $4.1 \%$ arginine (Chen et al., 2012). This condition decreased the excretion efficiency of this metabolite. Thus, the tilapia in the treatment with $4.1 \%$ arginine had their
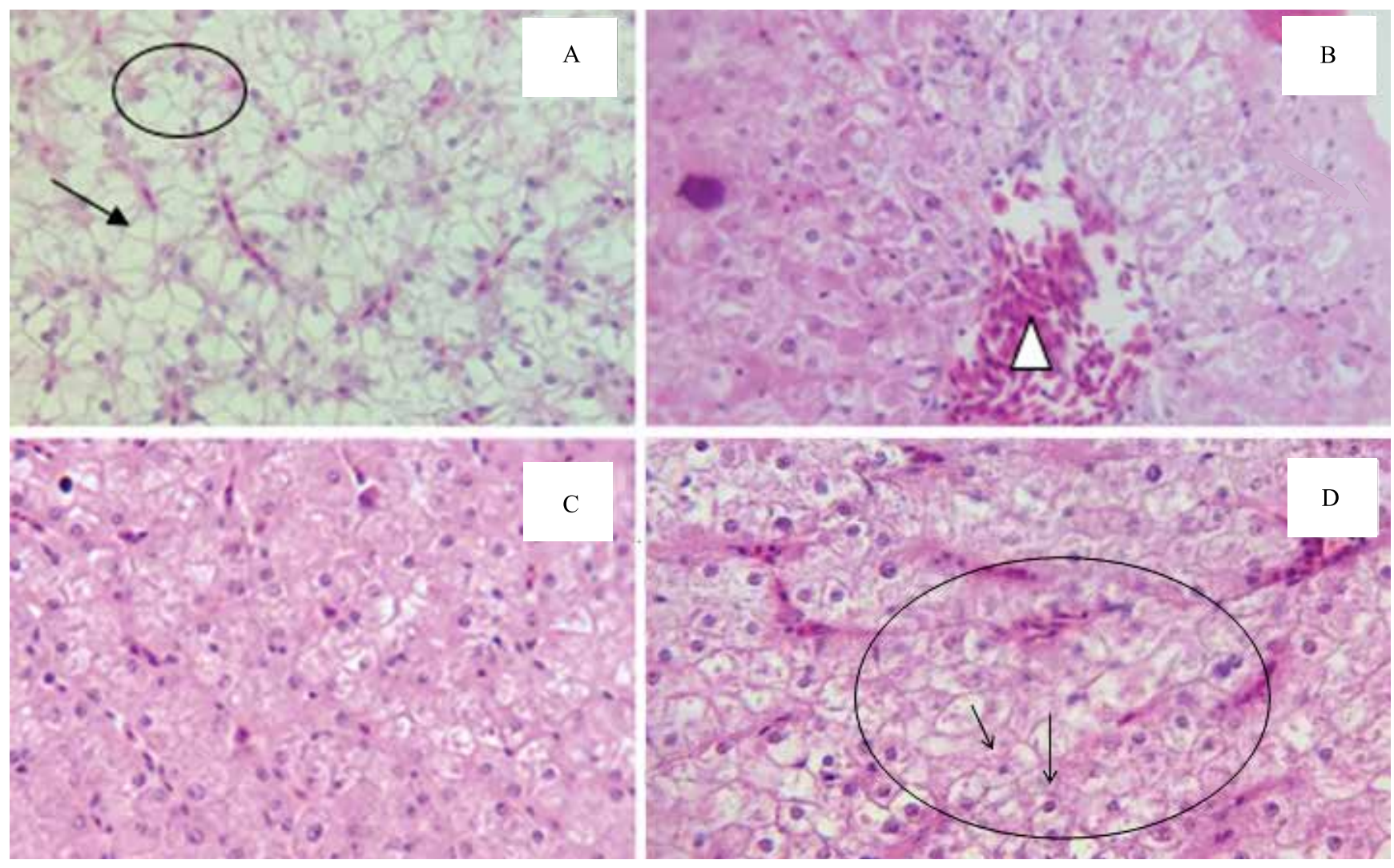

Figure 2. Photomicrography of liver of Nile tilapia (Oreochromis niloticus) produced in cages with arginine supplementation in the diet. A, control treatment, 2.3\% arginine - lipid degeneration (arrow), and vacuoles in the cytoplasm (circle), 400X, HE stain. B, 2.9\% arginine - blood congestion (triangle), 400X-HE. C, 3.5\% arginine, 400X, HE stain. D, 4.1\% arginine necrosis (circle) and pycnotic nuclei (arrows), 400X, HE stain. 
capacity to metabolize proteins compromised, which decreased the concentration of albumin (the main lipid carrier protein) in the plasma, and favored the increase of both lipid degeneration and ALT.

Leukocyte elevation may have contributed to the occurrence of pathologies observed in the liver of fish fed the diet with $4.1 \%$ of arginine, which allowed of the increase of nitric oxide in its inducible isoform, and respiratory burst, which led to the release of large amounts of free radicals for relatively long periods of time, and provoked toxic responses in the liver (Tibiriçá, 2001) and elevation of ALT.

Thus, it is evident the need to increase arginine concentration in the diets for tilapia juveniles in net cage cultivation, and the importance of new studies in large-scale production units with other species of commercial importance.

\section{Conclusion}

Arginine supplementation from $2.3 \%$ to $3.5 \%$ in diets for tilapia reared in cages does not influence fish productive performance; however, it improves the immune system of fish, without provoking deleterious morphological and physiological effects.

\section{Acknowledgments}

To Conselho Nacional de Desenvolvimento Científico e Tecnológico (CNPq), for financial support (project 470522/2012-7, and aid 305195/2016-6); and to R.Y. Fujimoto (305195/2016-6); to Ajinomoto, for the donation of arginine; to the Toca da Tilapia fish farm, for permission of the infrastructure use, as well as for feed and fish supply and assistance in the execution of field activities; and to Prevet for providing the water data of the property, during the experimental period.

\section{References}

BEHMER, O.A.; TOLOSA, E.M.C. de; FREITAS-NETO, A.G. de. Manual de técnicas para histologia normal e patológica. São Paulo: EDART, 1976. 241p.

BERGE, G.E.; LIED, E.; SVEIER, H. Nutrition of Atlantic salmon (Salmo salar): The requirement and metabolism of arginine. Comparative Biochemistry and Physiology Part A: Physiology, v.117A, p.501-509, 1997. DOI: https://doi.org/10.1016/ S0300-9629(96)00410-0.

BILLER-TAKAHASHI, J.D.; TAKAHASHI, L.S.; MARZOCCHI-MACHADO, C.M.; ZANUZZO, F.S.; SABIONI,
R.E.; URBINATI, E.C. Hemolytic activity of alternative complement pathway as an indicator of innate immunity in pacu (Piaractus mesopotamicus). Revista Brasileira de Zootecnia, v.41, p.237-241, 2012. DOI: https://doi.org/10.1590/S151635982012000200001 .

BILLER-TAKAHASHI, J.D.; TAKAHASHI, L.S.; SAITA, M.V.; GIMBO, R.Y.; URBINATI, E.C. Leukocytes respiratory burst activity as indicator of innate immunity of pacu Piaractus mesopotamicus. Brazilian Journal of Biology, v.73, p.425-429, 2013. DOI: https://doi.org/10.1590/s1519-69842013000200026.

CALABRESE, S.; NILSEN, T.O.; KOLAREVIC, J.; EBBESSON, L.O.E.; PEDROSA, C.; FIVELSTAD, S.; HOSFELD, C.; STEFANSSON, S.O.; TERJESEN, B.F.; TAKLE, H.; MARTINS, C.I.M.; SVEIER, H.; MATHISEN, F.; IMSLAND, A.K.; HANDELAND, S.O. Stocking density limits for post-smolt Atlantic salmon ( Salmo salar L.) with emphasis on production performance and welfare. Aquaculture, v.468, p.363-370, 2017. DOI: https://doi.org/10.1016/j.aquaculture.2016.10.041.

CENGİZLER, İ.; KÜÇÜKGÜL, A.; ŞAŞ, G. Seasonal changes in some hematological parameters in association with acted in oxygen transport in Nile tilapia (Oreochromis niloticus L). Eastern Anatolian Journal of Science, v.3, p.6-13, 2017.

CERQUEIRA, N.F.; YOSHIDA, W.B. Óxido nítrico: revisão. Acta Cirúrgica Brasileira, v.17, p.417-423, 2002. DOI: https:// doi.org/10.1590/s0102-86502002000600011.

CHEN, G.; FENG, L.; KUANG, S.; LIU, Y.; JIANG, J.; HU, K.; JIANG, W.; LI, S.; TANG, L.; ZHOU, X. Effect of dietary arginine on growth, intestinal enzyme activities and gene expression in muscle, hepatopancreas and intestine of juvenile Jian carp (Cyprinus carpio var. Jian). British Journal of Nutrition, v.108, p.195-207, 2012. DOI: https://doi.org/10.1017/S0007114511005459.

CHEN, G.; LIU, Y.; JIANG, J.; JIANG, W.; KUANG, S.; TANG, L.; TANG, W.; ZHANG, Y.-A.; ZHOU, X.; FENG, L. Effect of dietary arginine on the immune response and gene expression in head kidney and spleen following infection of Jian carp with Aeromonas hydrophila. Fish \& Shellfish Immunology, v.44, p.195-202, 2015. DOI: https://doi.org/10.1016/j.fsi.2015.02.027.

COLLIER, H.B. Standardization of blood haemoglobin determinations. Canadian Medical Association Journal, v.50, p.550-552, 1944.

FURUYA, W.M.; PEZZATO, L.E.; BARROS, M.M.; PEZZATO, A.C.; FURUYA, V.R.B.; MIRANDA, E.C. Use of ideal protein concept for precision formulation of amino acid levels in fishmeal-free diets for juvenile Nile tilapia (Oreochromis niloticus L.). Aquaculture Research, v.35, p.1110-1116, 2004. DOI: https:// doi.org/10.1111/j.1365-2109.2004.01133.x.

GOLDENFARB, P.B.; BOWYER, F.P.; HALL, E.; BROSIOUS, E. Reproducibility in the hematology laboratory: The microhematocrit determination. American Journal of Clinical Pathology, v.56, p.35-39, 1971. DOI: https://doi.org/10.1093/ ajcp/56.1.35.

HVAS, M.; FOLKEDAL, O.; SOLSTORM, D.; VÅGSETH, T.; FOSSE, J.O.; GANSEL, L.C.; OPPEDAL, F. Assessing swimming capacity and schooling behaviour in farmed Atlantic salmon Salmo 
salar with experimental push-cages. Aquaculture, v.473, p.423429, 2017. DOI: https://doi.org/10.1016/j.aquaculture.2017.03.013.

KAUSHIK, S.J.; FAUCONNEAU, B.; TERRIER, L.; GRAS, J. Arginine requirement and status assessed by different biochemical indices in rainbow trout (Salmo gairdneri R.). Aquaculture, v.70, p.75-95, 1988. DOI: https://doi. org/10.1016/0044-8486(88)90008-7.

LI, P.; MAI, K.; TRUSHENSKI, J.; WU, G. New developments in fish amino acid nutrition: towards functional and environmentally oriented aquafeeds. Amino Acids, v.37, p.43-53, 2009. DOI: https://doi.org/10.1007/s00726-008-0171-1.

LIN, H.; TAN, X.; ZHOU, C.; NIU, J.; XIA, D.; HUANG, Z.; WANG, J.; WANG, Y. Effect of dietary arginine levels on the growth performance, feed utilization, non-specific immune response and disease resistance of juvenile golden pompano Trachinotus ovatus. Aquaculture, v.437, p.382-389, 2015. DOI: https://doi.org/10.1016/j.aquaculture.2014.12.025.

MARENGONI, N.G.; MAHL, I.; ALBUQUERQUE, D.M.; MOURA, M.C.; SANCHES, E.A.; PIANA, P.A. Formato e área de comedouros em tanques-rede para juvenis de tilápia do Nilo. Archivos de Zootecnia, v.66, p.567-577, 2017. DOI: https://doi. org/10.21071/az.v66i256.2774.

OJWALA, R.A.; OTACHI, E.O.; KITAKA, N.K. Effect of water quality on the parasite assemblages infecting Nile tilapia in selected fish farms in Nakuru County, Kenya. Parasitology Research, v.117, p.3459-3471, 2018. DOI: https://doi.org/10.1007/ s00436-018-6042-0.

OLIVA-TELES, A.; PERES, H.; KAUSHIK, S. Dietary arginine supplementation does not improve nutrient utilisation in gilthead seabream. Aquaculture, v.479, p.690-695, 2017. DOI: https://doi. org/10.1016/j.aquaculture.2017.07.016.

RAHIMNEJAD, S.; LEE, K.-J. Dietary arginine requirement of juvenile red sea bream Pagrus major. Aquaculture, v.434, p.418424, 2014. DOI: https://doi.org/10.1016/j.aquaculture.2014.09.003.

RODNICK, K.J.; PLANAS, J.V. The stress and stress mitigation effects of exercise: cardiovascular, metabolic, and skeletal muscle adjustments. In: SCHRECK, C.B.; TORT, L.; FARRELL, A.P.; BRAUNER, C.J. (Ed.). Biology of Stress in fish. Amsterdam: Elsevier, 2016. p.251-294. (Fish physiology, 35). DOI: https://doi. org/10.1016/B978-0-12-802728-8.00007-2.

SAAD, E.A. Curative and protective effects of 1-arginine on carbon tetrachloride-induced hepatotoxicity in mice. Biochemical and Biophysical Research Communications, v.423, p.147-151, 2012. DOI: https://doi.org/10.1016/j.bbrc.2012.05.102.
SADHU, N.; SHARMA, S.R.K.; JOSEPH, S.; DUBE, P.; PHILIPOSE, K.K. Chronic stress due to high stocking density in open sea cage farming induces variation in biochemical and immunological functions in Asian seabass (Lates calcarifer, Bloch). Fish Physiology and Biochemistry, v.40, p.1105-1113, 2014. DOI: https://doi.org/10.1007/s10695-014-9909-8.

SALES, R.P.; MINÉ, C.E.C.; FRANCO, A.D.; RODRIGUES, É.L.; PELÓGIA, N.C.C.; SILVA, R. de S. e; COGO, J.C.; LOPESMARTINS, R.A.B.; OSORIO, R.L.; RIBEIRO, W. Efeitos da suplementação aguda de aspartato de arginina na fadiga muscular em voluntários treinados. Revista Brasileira de Medicina do Esporte, v.11, p.347-351, 2005. DOI: https://doi.org/10.1590/ S1517-86922005000600008.

SILVA, L.B.; GONÇALVES, P. Degeneração gordurosa (lipidose hepática). Revista Científica Eletrônica de Medicina Veterinária, v.10, 2008. Não paginado.

TIBIRIÇÁ, E. Fisiopatologia em medicina cardiovascular. São Paulo: Revinter, 2001. 344p.

TU, Y.; XIE, S.; HAN, D.; YANG, Y.; JIN, J.; ZHU, X. Dietary arginine requirement for gibel carp (Carassis auratus gibelio var. CAS III) reduces with fish size from $50 \mathrm{~g}$ to $150 \mathrm{~g}$ associated with modulation of genes involved in TOR signaling pathway. Aquaculture, v.449, p.37-47, 2015. DOI: https://doi.org/10.1016/j. aquaculture.2015.02.031.

WINTROBE, M.M. Variations in the size and hemoglobin content of erythrocytes in the blood of various vertebrates. Folia Haematologica, v.51, p.32-49, 1934.

ZAGO, A.C.; FRANCESCHINI, L.; GARCIA, F.; SCHALCH, S.H.C.; GOZI, K.S.; SILVA, R.J. da. Ectoparasites of Nile tilapia (Oreochromis niloticus) in cage farming in a hydroelectric reservoir in Brazil. Revista Brasileira de Parasitologia Veterinária, v.23, p.171-178, 2014. DOI: https://doi.org/10.1590/ s1984-29612014041.

ZEHRA, S.; KHAN, M.A. Dietary arginine requirement of fingerling Indian major carp, Catla catla (Hamilton). Journal of the World Aquaculture Society, v.44, p.363-373, 2013. DOI: https://doi.org/10.1111/jwas.12046.

ZHOU, Q.; JIN, M.; ELMADA, Z.C.; LIANG, X.; MAI, K. Growth, immune response and resistance to Aeromonas hydrophila of juvenile yellow catfish, Pelteobagrus fulvidraco, fed diets with different arginine levels. Aquaculture, v.437, p.84-91, 2015. DOI: https://doi.org/10.1016/j.aquaculture.2014.11.030. 